\title{
Analysis of Factors Related To Adolescents Preparedness in The Disaster-Prone Areas in Lempake Village, Samarinda
}

\author{
Dwi Rahmah Fitriani*, Alfi Ari Fakhrur Rizal, Milkhatun, Mukhripah Damaiyanti, \\ Ni Wayan Wiwin Astiningsih \\ Universitas Muhammadiyah Kalimantan Timur, Samarinda, Indonesia \\ *drf397@umkt.ac.id
}

\begin{abstract}
Disaster-prone area can have an impact on changes in the nearby people, both physically and psychologically. The impact of these changes can be minimized by paying attention to the pre-disaster phase, namely preparedness that can be carried out by the productive age adolescence as the stakeholders. The purpose of this study was to determine the relation between anxiety factors, coping mechanisms and social support with the preparedness of adolescents in disaster-prone areas in Lempake Village, Samarinda. This research was a quantitative study using a cross sectional design, with data collection techniques using a questionnaire. Respondents in this study were 606 people. The results of this study indicated that the characteristics of the respondents were mostly in their early adolescence with 408 people $(67.8 \%), 346$ women $(57.1 \%)$ and 317 people with a high school education background (53.4\%). \%). Most of the respondents for the anxiety factor having moderate anxiety were 436 people $(71.9 \%)$, the coping mechanism factor of the respondents having an adaptive coping mechanism were 338 people $(55.8 \%)$ and the respondents' social support factor having good social support were 319 people $(52.6 \%)$ and most of the respondents (349 people (57.6\%)) had a good preparedness. The results of the bivariate analysis showed that the p value $<\alpha(\alpha=0.05, \mathrm{CI} ; 95 \%)$ which indicates that there is a relationship between anxiety factors, coping mechanisms and social support with adolescent preparedness. Then, the results of multivariate analysis using Logistic Regression (OR value: 5.1) found that the anxiety factor was the most significant factor associated with adolescent preparedness. The results of the study suggest that preparedness should be carried out by involving the government and local Health facilities (Puskesmas) as well as the Regional Disaster Management Agency through disaster preparedness training.
\end{abstract}

Keywords: Social Support, Anxiety, Preparedness, Coping Mechanisms, Adolescents 


\section{STRADA Jurnal Ilmiah Kesehatan}

DOI: $10.30994 /$ sjik.v9i2.489

ISSN: 2252-3847 (print); 2614-350X (online)

Vol.9 No.2 November 2020 Page.1434-1444

\section{BACKGROUND}

Flood is disaster that often occur every year as a result of high rainfall, where the water limit exceeds the limit of river flows, lakes or reservoirs so that it can disrupt people's lives in many sectors. It can soak the facilities and infrastructure, deter economic activities, hinder teaching and learning systems or even in the extreme cases flood can be deadly. Based on data from the National Disaster Management Agency, there were 1046 flood disasters out of a total of 3999 disasters during the 2018-2019 period and many resulted in casualties and damage to houses and public facilities (BNPB, 2019). The number of the impact of flood in people's lives in the form of deaths was $56 \%$, and the economy was 32\% (Mami \& Debarati, 2017). The data above shown us that the predisaster efforts are needed so it can negate the bad impacts. In this article we will examine one of the pre-disaster phases namely preparedness effort that is essential especially in the disaster-prone area. Preparedness is needed in the disaster-prone areas such as Lempake Village in Samarinda city which is located close to a water reservoir from the rivers.

Preparedness is an activity to develop plans to minimize the risks and reduce negative impacts through coordinated activities, integrated with the ability to respond quickly and appropriately using existing resources and the involvement of various parties (Stikova, 2016). Previous research shows that 575 (95\%) respondents in Nigeria who are in flood-prone areas did not carry out preparedness before the occurrence of flood disasters and only $25(5 \%)$ of respondents did preparedness before the coming flood period (Mary \& Emeribe, 2014).

Preparedness is the effective steps taken aimed to prevent disaster before a disaster occurs so that people in disaster-prone areas are ready to react to various emergency conditions when a disaster does occur. Efforts to increase preparedness highly require an active participation from the community to strengthen the preparedness of the community in disaster-prone area using the community-based approach especially for the youth groups (Hasrul, Sri, \& Armin, 2019). Youth groups are groups of people who fall into the category of adolescence. In this stage, adolescents begin to be able to accept social responsibility and begin to enter an independent phase in their lives so that they can anticipate and handle disaster situations or even contribute in the emergency action such as saving both lives and property.

Adolescents in disaster-prone areas have a higher responsibility to be able to be involved in disaster preparedness and this capability can be increased through knowledge. The previous research shown that knowledge and attitudes had an influence on the preparedness of adolescents aged 15-18 years in facing floods with a determination coefficient of 0.636 or $63.6 \%$ (Alif, Sunarko, \& Saptono, 2015). The knowledge possessed by adolescents in disaster-prone areas depicted the efforts that had been made to anticipate and adapt in the pre-disaster phase, especially in the preparedness phase. This is a coping mechanism effort that can be done when individuals are in disaster-prone areas.

Living in a disaster-prone area can also cause psychological problems such as anxiety. The prior study of 28 participants living in the volcanic route of Southern Iceland contributed through in-depth interviews revealed that they often thought about the risk of eruptions, the children were sometimes frightened as a respond of living in the area around the eruption route and sometimes the family became anxious (Johannesdottir \& Gisladottir, 2015). Anxiety is a condition that occurs as a result of a response to the unknown or uncomfortable feeling caused by the anticipation of danger and it is a reaction of survival. The feeling of discomfort felt by adolescents in Lempake Village was likely 


\section{STRADA Jurnal Ilmiah Kesehatan}

DOI: $10.30994 /$ sjik.v9i2.489

ISSN: 2252-3847 (print); 2614-350X (online)

Vol.9 No.2 November 2020 Page.1434-1444

due to the fact that they are living in a flood-prone area that can affect their way of thinking and their perspective on potential disasters.

In a such disaster-prone area, an adequate social support is needed in preparing the community, especially the youth, so they can carry out preparedness and to minimize the impact that occurs when a flood disaster occurs. This social support can be in the form of information of what things needed to be prepared in the event of a flood, the evacuation routes, the supporting facilities such as the shelter, the evacuation equipments, etc. People living in a flood-risk area also need a good management system through planning, communication, evacuation and preparation in emergency situations (Raikes, Timothy, Christine, \& Claudia, 2019). This social support can change adolescent behaviours in preparing for flood disasters in the preparedness phase. Preparedness needs to be carried out appropriately and adequately by taking into account about the factors that can highly impact the preparedness of adolescents in disaster-prone areas of Lempake Village. This study aims to identify the relationship between anxiety factors, coping mechanisms and social support with adolescents preparedness in disaster-prone areas.

\section{METHOD}

This research was a quantitative study using a cross sectional design, in which the researcher describes and analyses the relationship between the variables studied. Respondents in this study were adolescents aged 12-25 years at National Junior High School 13 (SMPN 13) and National Senior High School 9 (SMA 9) in the Lempake village area. The village close to a Benanga reservoir which is a reservoir for the Karang Mumus tributary, where the school is only 4-6 km from the reservoir. The last few years, the frequent flood occurred with high depths because of the overflown reservoir water due to high rainfall. The flood submerged the area around the dam, including schools and the surrounding area of Lempake village. The number of respondents in this study were 606 people with the sampling technique using Stratified Random Sampling and this research was conducted from June to July 2020.

The independent variables in this study were anxiety, coping mechanisms and social support, while the dependent variable was preparedness. Measurements for anxiety variables used the Trait Anxiety Scale questionnaire (Rodrigues, Pandeirada, \& Bem-haja, 2018), coping mechanisms used the Cope Brief questionnaire (Tuncay, Ilgen, Engin, \& Mustafa, 2014) and social support used the Social Provisions Scale questionnaire. (Orpana \& Lang, 2019).

Questionnaire of preparedness, this research used the Flood Preparedness Index (Mishra, Mazumdar, \& Suar, 2010). The results of the reliability test conducted by the researcher showed the results for the questionnaire The Trait Anxiety Scale had Cronbach's $\alpha$ 0.701, Brief Cope had Cronbach's $\alpha$ 0.843, The Social Provisions Scale had Cronbach's $\alpha 0.883$ while the questionnaire Flood Preparedness Index had Cronbach's $\alpha$ 0.877 (Fitriani et al., 2019).

The analysis used was univariate analysis to see the description of the characteristics of respondents with frequency distribution and bivariate analysis to determine the relationship between anxiety variables, coping mechanisms and social support with the adolescent preparedness variable using chi square. In this study, multivariate analysis was also carried out using logistic regression to see which variables were most associated with adolescent preparedness.

Approval of this research has been given by the Ethical Test Committee of Universitas Muhammadiyah Kalimantan Timur with Number: 002/KEPK-UMKT/I/2020 


\section{STRADA Jurnal Ilmiah Kesehatan}

DOI: $10.30994 /$ sjik.v9i2.489

ISSN: 2252-3847 (print); 2614-350X (online)

Vol.9 No.2 November 2020 Page.1434-1444

and all the teenagers involved in this research are willing to participate in research and giving consent to be involved in this research.

\section{RESULTS}

This study involved a number of 606 respondents in SMP 13 and SMA 9, Lempake Samarinda, which were a flood-prone areas. The characteristics of the respondents in this research are:

Table 1. Distribution of Respondents by Age

\begin{tabular}{cccc}
\hline No & Age & N & $(\%)$ \\
\hline 1. & $12-16$ Year & 408 & 67,8 \\
\hline 2. & $17-25$ Year & 198 & 32,2 \\
\hline Total & & 606 & 100 \\
\hline
\end{tabular}

Source: Primary Data, 2020

Table 1 showed that of the 606 adolescent respondents, most of them were in the age range 12-16 years, a total of 408 respondents $(67.8 \%)$ were included in the early adolescence stage and 198 respondents $(32.2 \%)$ respondents were in the age range 17-25. years that were in the stage of late adolescence.

Table 2. Distribution of Respondents by Gender

\begin{tabular}{clcc}
\hline No & Gender & N & $(\%)$ \\
\hline 1. & Male & 260 & 42,9 \\
\hline 2. & Female & 346 & 57,1 \\
\hline Total & & 606 & 100
\end{tabular}

Source: Primary Data, 2020

Table 2 showed that female respondents were higher than male respondents. Female accounted for 346 respondents (57.1) while male respondents were 260 respondents (42.9).

Furthermore, the description of adolescents who experienced anxiety, the coping mechanisms possessed by adolescents and the social support received by adolescents as well as youth preparedness in disaster-prone areas are:

Table 3. Overview of Respondents' Anxiety Level

\begin{tabular}{llrc}
\hline No & Anxiety Level & $\mathrm{N}$ & $(\%)$ \\
\hline 1. & Moderate & 118 & 19,5 \\
\hline 2. & Mild & 436 & 71,9 \\
\hline 3. & Severe & 52 & 8.6 \\
\hline Total & & 606 & 100 \\
\hline
\end{tabular}

Source: Primary Data, 2020

Table 3 showed that the anxiety level of adolescents in disaster-prone areas mostly experienced moderate anxiety of 435 respondents (71.9\%), 118 respondents had mild anxiety $(19.5 \%)$ and 52 respondents had severe anxiety levels $(8,6 \%)$. 


\section{STRADA Jurnal Ilmiah Kesehatan}

DOI: $10.30994 /$ sjik.v9i2.489

ISSN: 2252-3847 (print); 2614-350X (online)

Vol.9 No.2 November 2020 Page.1434-1444

Table 4. Overview of Respondents' Coping Mechanisms

\begin{tabular}{clcl}
\hline No & Coping Mechanisms & N & $(\%)$ \\
\hline 1. & Adaptive & 338 & 55,8 \\
\hline 2. & Maladaptive & 268 & 44,2 \\
\hline Total & & 606 & 100
\end{tabular}

Source: Primary Data, 2020

Table 4 showed the results that most respondents used adaptive coping mechanisms which was as much as 338 respondents (55.8\%) while in the disaster area and 268 (44.2\%) respondents who used maladaptive coping.

Table 5. Overview of Respondents' Social Support

\begin{tabular}{clcc}
\hline No & Social Support & N & $(\%)$ \\
\hline 1. & Well & 319 & 52,6 \\
\hline 2. & Bad & 287 & 47,4 \\
\hline Total & & 606 & 100
\end{tabular}

Source: Primary Data, 2020

Table 5 showed the social support felt by adolescents from the surrounding environment, where most of the adolescents received well social support, which was as much as 319 respondents $(52.6 \%)$ and 287 respondents $(47.4 \%)$ received bad social support.

Table 6. Overview of Respondents' Preparedness

\begin{tabular}{clrl}
\hline No & Preparedness & N & $(\%)$ \\
\hline 1. & Well & 349 & 57,6 \\
\hline 2. & Bad & 257 & 42,4 \\
\hline Total & & 606 & 100 \\
\hline
\end{tabular}

Source: Primary Data, 2020

Table 6 showed that the preparedness of adolescents in disaster-prone areas was mostly good which was as much as 349 respondents (57.6\%) and 257 respondents (42.4\%) was poor.

Analysis of the relationship between anxiety, coping mechanisms and social support with adolescent preparedness can be described as follows:

Table 7. Chi-Square Test Results between Anxiety Level and Adolescents Preparedness

\begin{tabular}{|c|c|c|c|c|c|c|c|}
\hline \multirow{3}{*}{ Kecemasan } & \multicolumn{4}{|c|}{ Preparedness } & \multirow{2}{*}{\multicolumn{2}{|c|}{ Total }} & \multirow{3}{*}{$P$ Value } \\
\hline & \multicolumn{2}{|c|}{ Well } & \multicolumn{2}{|c|}{ Bad } & & & \\
\hline & $\mathrm{n}$ & $\%$ & $\mathrm{n}$ & $\%$ & $\mathrm{n}$ & $\%$ & \\
\hline Low & 29 & 55,8 & 23 & 44,2 & 52 & 100 & \\
\hline Medium & 264 & 60,6 & 172 & 39,4 & 436 & 100 & 0,037 \\
\hline High & 56 & 47,5 & 62 & 52,5 & 118 & 100 & \\
\hline
\end{tabular}

Source: Primary Data, 2020

Table 7 showed that there were $264(60.6 \%)$ adolescents who experienced moderate anxiety, had good preparedness and 172 (39.4\%) adolescents who experienced moderate 


\section{STRADA Jurnal Ilmiah Kesehatan}

DOI: $10.30994 /$ sjik.v9i2.489

ISSN: 2252-3847 (print); 2614-350X (online)

Vol.9 No.2 November 2020 Page.1434-1444

anxiety, had poor preparedness. Meanwhile $62(52.5 \%)$ adolescents who experienced severe anxiety had poor preparedness and $56(47.5 \%)$ adolescents who experienced severe anxiety had good preparedness. The statistical test results obtained $\mathrm{p}$ value $=0.037$ ( $\mathrm{p}$ $<0.05$ ), it can be concluded that there was a significant relationship between anxiety and adolescent preparedness in flood-prone areas, Lempake Village, Samarinda.

Table 8. Chi-Square Test Results between Coping Mechanism and Adolescents Preparedness

\begin{tabular}{|c|c|c|c|c|c|c|c|}
\hline \multirow{3}{*}{ Coping Mechanism } & \multicolumn{4}{|c|}{ Preparedness } & \multirow{2}{*}{\multicolumn{2}{|c|}{ Total }} & \multirow{3}{*}{$P$ Value } \\
\hline & \multicolumn{2}{|c|}{ Well } & \multicolumn{2}{|c|}{$\mathrm{Bad}$} & & & \\
\hline & $\mathrm{n}$ & $\%$ & $\mathrm{n}$ & $\%$ & $\mathrm{n}$ & $\%$ & \\
\hline Adaptive & 207 & 61,2 & 131 & 38,8 & 338 & 100 & 004 \\
\hline Maladaptive & 142 & 53 & 126 & 47 & 268 & 100 & 0,041 \\
\hline
\end{tabular}

Source: Primary Data, 2020

Table 8 showed that there were 207 (61.2\%) adolescents who had adaptive coping mechanisms, displaying good preparedness and 142 (53\%) adolescents who had maladaptive coping mechanisms, displaying good preparedness. Meanwhile, $131(38.8 \%)$ adolescents who had adaptive coping mechanisms displaying poor preparedness and 126 (47\%) adolescents who had maladaptive coping mechanisms displaying poor preparedness. The statistical test results obtained $\mathrm{p}$ value $=0.041(\mathrm{p}<0.05)$, it can be concluded that there was a significant relationship between coping mechanism and adolescents preparedness in flood-prone areas, Lempake Village, Samarinda.

Table 9. Chi-Square Test Results between Social Support and Adolescents Preparedness

\begin{tabular}{lccccccc}
\hline \multirow{2}{*}{ Social Support } & \multicolumn{3}{c}{ Preparedness } & \multirow{2}{*}{ Total } & \multirow{2}{*}{ P Value } \\
\cline { 2 - 7 } & \multicolumn{2}{c}{ Well } & \multicolumn{2}{c}{ Bad } & & \\
\cline { 2 - 7 } & $\mathrm{n}$ & $\%$ & $\mathrm{n}$ & $\%$ & $\mathrm{n}$ & $\%$ & \\
\hline Well & 200 & 57,3 & 119 & 46,3 & 319 & 100 & \multirow{2}{*}{0,009} \\
\hline Bad & 149 & 42,7 & 138 & 53,7 & 287 & 100 & \\
\hline
\end{tabular}

Source: Primary Data, 2020

Table 9 showed that there were 200 (57.3\%) adolescents who got good social support, had good preparedness and $149(42.7 \%)$ adolescents who got poor social support, had good preparedness. Meanwhile, 138 (53.7\%) adolescents who received poor social support had poor preparedness and $119(46.3 \%)$ adolescents who received good social support had poor preparedness. The results of statistical tests obtained $\mathrm{p}$ value $=0.009(\mathrm{p}<0.05)$, it can be concluded that there was a significant relationship between social support and adolescent preparedness in flood-prone areas, Lempake Village, Samarinda.

Table 10. Logistic Regression Factors Associated with Adolescents Preparedness in Disaster Prone Areas

\begin{tabular}{clcccc}
\hline No & \multicolumn{1}{c}{ Variable } & B & $p$ value & OR & CI 95\% \\
\hline 1. & Coping Mechanism & $-7,788$ & 0,003 & 0,000 & $0,000-0,070$ \\
2. & Anxiety & 8,514 & 0,000 & 5,135 & $3,978-5,230$ \\
3. & Social Support & $-1,219$ & 0,013 & 0,277 & $0,085-0,763$ \\
& Constant & 19,145 & & & \\
\hline
\end{tabular}

Source: Primary Data, 2020

Table 10 showed that after the final modeling, the most significant variable with the greatest OR value was anxiety factor with a value of 5.1, which means that adolescents 


\section{STRADA Jurnal Ilmiah Kesehatan}

DOI: $10.30994 /$ sjik.v9i2.489

ISSN: 2252-3847 (print); 2614-350X (online)

Vol.9 No.2 November 2020 Page.1434-1444

who experience anxiety have a 5.1 times chance of having disaster-prone areas preparedness.

\section{DISCUSSION}

\section{A. Relationship between Anxiety Level and Adolescents Preparedness}

Adolescents living in disaster-prone areas (around age 12-16 years and 17-25 years), were starting to have physical and emotional maturity levels to be independent and this study described the ability of adolescents to adapt to disaster-prone areas according to their duties and responsibilities at each stage of a disaster. Because in the adaptation process, especially in the preparedness stage, can cause other effects in the form of anxiety because they are in a disaster-prone area.

The results of this study indicated that there was a relationship between anxiety and adolescent preparedness with a value of $\mathrm{p}=0.037(\mathrm{p}<0.05)$, where most of the respondents were $264(60.6 \%)$ adolescents who experienced moderate anxiety and had good preparedness. Adolescents who experienced moderate anxiety had a good preparedness in flood-prone areas. Flood is an event that has an impact on an individual's life, where the damage occurs so that it can create depression and fear based on an ongoing anxiety response. Based on Freud's Anxiety Theory, anxiety is a natural state of a person in a state of shock and fear that occurs from environmental conditions that can have an effect on life (Johari \& Marzuki, 2013). This was also in line with the results of research conducted at the social service of Aceh Province showing that anxiety in 68 respondents was at a total score of 2,718 in the moderate category and preparedness was at a score of 2,964 in the high category during earthquake readiness (Surbariyanti, Agussabti, \& Imran, 2019 ).

Adolescents living in disaster-prone areas have high preparedness so they show moderate symptoms of anxiety. When the individual is in moderate anxiety, the individual becomes more focused and attentive to the main things so that they can do something more directed. The moderate anxiety experienced by adolescents in this study was caused by unpredictable disasters, being in a disaster-prone location and the frequency of flood each year due to high rainfall. The impact of the moderate anxiety response experienced by adolescents in flood-prone areas had an impact on adolescents' ability to prepare themselves for floods so that adolescents have good preparedness.

\section{B. Relationship between Coping Mechanism and Adolescents Preparedness}

The coping mechanism is an effort made by individuals directed at managing stress, which can be constructive and destructive in nature (Stuart GW, 2013). Adolescent coping mechanisms when in disaster-prone areas need to be developed constructively so that they can make efforts in the preparedness stage to reduce stress by taking into account external and internal factors that have a direct impact on adolescents' efforts to have adaptive coping mechanisms. Adolescents living in disaster-prone areas will have an adaptive coping mechanism, as a physiological effort made to survive and take responsibility to be independent in facing stressors in their lives.

The results of this study indicated that there was a significant relations between coping mechanisms and adolescent preparedness in flood-prone areas Lempake Samarinda with a value of $\mathrm{p}=0.041$ ( $\mathrm{p}<0.05)$, where most of the respondents were $207(61.2 \%)$ adolescents who had the mechanism, adaptive coping, displaying good preparedness. This occurred because the ability of adolescents to adapt to disaster-prone areas, which was formed due to their experiences in dealing with floods. It highly impacted their 


\section{STRADA Jurnal Ilmiah Kesehatan}

DOI: $10.30994 /$ sjik.v9i2.489

ISSN: 2252-3847 (print); 2614-350X (online)

Vol.9 No.2 November 2020 Page.1434-1444

preparedness. The prior research also agreed that there was a relations between a past experience toward disaster preparedness with a correlation value of 0.566 (Muhammad \& Aziz K, 2014). Other studies also shown that individuals who had experienced a disaster before had $39.6 \%$ impact on their ways of thinking and self-awareness, $25 \%$ impact on self-awareness as well as the efforts to increase the knowledge of preparedness and $27.1 \%$ impact on their efforts to develop preparedness (Becker, Paton, Johnston, Kevin, \& John, 2017).

The coping mechanism is also formed through the process of adapting to disaster sources when in disaster-prone areas. With a good coping mechanism, the preparedness efforts made by youth will also be good. This adaptation process can also be pursued by obtaining information about preparedness efforts that need to be carried out when in flood-prone areas, such as making plans, evacuation routes, tools and equipment needed when a flood occurs. In line with this, the results of research shown that there was a significant relationship between knowledge and landslide disaster preparedness $(\mathrm{p}=$ 0.000, $\alpha=0.05$ ) (Setyo, Dima, \& Widya, 2019).

Another study of a semistructured survey of respondents had a strategy for dealing with storms, where $43 \%$ protected the house by strengthening the roof, $18 \%$ of the respondents protected their family by choosing a safe shelter and $32 \%$ of respondents stored food when the storm came back (Lalaina et al., 2016) ( Shay, Combs, Salvesen, Detrizio, \& Horney, 2014).

Good youth preparedness in disaster-prone areas is a form of good coping mechanisms and efforts made by always opening oneself to get good adaptation habits in disasterprone areas. A constructively developed coping mechanism in disaster areas can make youth responsible to prepare themselves to be ready for disaster whenever needed especially in flood-prone areas. This coping mechanism can be improved through training or providing information in conducting preparedness before a flood occurs.

\section{Relationship between Social Support and Adolescents Preparedness}

Social support is the feedback received by individuals as a form of attention and appreciation that involves family, friends and the environment around the individual. Social support is one of the sources of individual coping in overcoming stressors that occur in their lives (Stuart GW, 2013). The existence of social support, especially family and peers, is very important in making decisions when you are in a disasterprone area because you can exchange information, experiences and exchange opinions in preparing for floods.

The results of this study indicated that there was a significant relationship between coping mechanisms and youth preparedness in flood-prone areas Lempake Samarinda with a value of $\mathrm{p}=0.041$ ( $\mathrm{p}<0.05$ ), where most of the 200 respondents $(57.3 \%)$ got good social support, had good preparedness. The results of a prior research of a qualitative approach to 18 adolescents who were affected by the earthquake in Lombok had the similar research themes, one of which the social support was provided during adaptation after the earthquake in the form of emotional and instrumental support (Nova, Ah, \& Dian, 2019), those can be given before a disaster occurs so they can prepare themselves to help others during disaster.

Another study showed that respondents who received emotional and instrumental support prior to a disaster had significantly smaller 1.34 (95\% CI: 1.03-1.74) symptoms of depression after a disaster occurs compared to respondents who had less social support 1.70 (95\% CI: 1.03-2.76) (Sasaki et al., 2019). The support provided in the 


\section{STRADA Jurnal Ilmiah Kesehatan}

DOI: $10.30994 /$ sjik.v9i2.489

ISSN: 2252-3847 (print); 2614-350X (online)

Vol.9 No.2 November 2020 Page.1434-1444

preparedness phase for adolescents can have a huge impact in preparing themselves, especially after a disaster occurs. This social support will improve the ability of adolescents to prepare themselves and increase awareness when in flood-prone areas. This support can be in the form of supporting information related to preparations that need to be done before a disaster strikes, preparedness plans and supporting facilities in the event of a disaster such as evacuation routes and places as well as the availability of transportation equipment used during floods.

\section{Anxiety Level is Very Related to Adolescents Preparedness}

The results of the logistic regression test on the factors that were likely to be closely related to adolescent preparedness showed that the most significant factor with the greatest OR value anxiety factor with a value of 5.1, which means that adolescents who experienced anxiety have a 5.1 times chance of having preparedness in the disasterprone areas. Other studies showed that anxiety had a very significant relationship $(\mathrm{P}=$ 0.002) with self-preparedness to face disasters, the level of perception and the ability of respondents to determine the right strategy (Lee \& Haeyoung Lee, 2019).

The results showed that most people who live in flood-prone areas experienced moderate anxiety of 40\% (Lamba, Herdy, \& Kandou, 2017). The feeling of worry and fear can increase the awareness and self-protection, This negative emotion can be an important factor in the mitigation measures that support preparedness.

Anxiety is a physiological response of an individual in a disaster-prone area because of the many stressors that occur. These stressors can increase the ability of adolescents in their preparedness in disaster-prone areas. It occurs as a result of the narrowing point of view of them so that they are more focus, more alert and solely concentrate on stressors. As a result, some of adolescents are motivate to increase their independence to help themselves and others in disaster preparedness as an effort to prevent a bigger impact during a disaster and to alleviate the consequences after a disaster occurs

\section{CONCLUSION}

Preparedness is an action that needs to be taken before a disaster occurs to avoid and prevent negative impacts during the disaster and after the disaster. especially for the youth living in the disaster-prone area who are starting to become independent and responsible for themselves and their families who also live in there. The results of the discussion in this study indicated that there was a relationship between anxiety factors, coping mechanism and social support with youth preparedness in disaster-prone areas of Lempake Village, Samarinda.

Efforts are needed to prevent the occurrence of worsening and prolonged anxiety of adolescents living in disaster-prone areas, the adaptive coping mechanisms and a very good social support are needed so they can improve their disaster preparedness abilities to help themselves himself and his family. The anxiety is actually very related to preparedness efforts because when experiencing the manageable anxiety level, adolescents become more focused on problems when facing stressors. Efforts that needed to be made in preparedness are a good planning, the availability of supporting facilities, and the community-based disaster preparedness training so that when a disaster occurs, the community, especially teenagers, can be resilient and better prepared in facing flood disasters by involving involvement government and local health centers. 


\section{STRADA Jurnal Ilmiah Kesehatan}

DOI: $10.30994 /$ sjik.v9i2.489

ISSN: 2252-3847 (print); 2614-350X (online)

Vol.9 No.2 November 2020 Page.1434-1444

\section{REFERENCES}

Alif, P., Sunarko, \& Saptono, P. (2015). Pengaruh Pengetahuan Dan Sikap Tentang Resiko Bencana Banjir Terhadap Kesiapsiagaan Remaja Usia 15 - 18 Tahun Dalam Menghadapi Bencana Banjir Di Kelurahan Pedurungan Kidul Kota Semarang. Jurnal Geografi, 12(2), 214-221.

Becker, J., Paton, D., Johnston, D. M., Kevin, R., \& John, M. (2017). The role of prior experience in informing and motivating earthquake preparedness. International Journal of Disaster Risk Reduction, 22(March), 179-193. https://doi.org/10.1016/j.ijdrr.2017.03.006

BNPB. (2019). Data Informasi Bencana Indonesia. Retrieved from 2019 website: http://bnpb.cloud/dibi/tabella

Fitriani, D. R., Damaiyanti, M., Milkhatun, Astiningsih, N. W., Fachrurizal, A., \& Muflihatin, S. K. (2019). The Relation Between Knowledge and Experience of Facing Flood Toward The Anxiety Level of Head Families in The Flood-Prone Areas. Soouth East Asia Nursing Research, 1(3), 120-127. https://doi.org/https://doi.org/10.26714/seanr.1.3.2019.120-127

Hasrul, H., Sri, A., \& Armin, S. (2019). Penguatan Kesiapsiagaan Stakeholder Dalam Pengurangan Risiko Bencana Gempa Bumi. Jurnal Geodika, 3, 30-40.

Johannesdottir, G., \& Gisladottir, G. (2015). Vulnerability and Risk Perception People Living Under Threat of Volcanic Hazard in Southern Iceland : Vulnerability and Risk Perception. Natural Hazards and Earth System Sciences, 10(February 2010), 407420. https://doi.org/10.5194/nhess-10-407-2010

Johari, J., \& Marzuki, N. A. (2013). Relating Stress , Anxiety and Depression among Flood Victims ' Quality of Life in Malaysia: A Theoretical Perspective. International Journal of Social Science and Humanity, 3(6), 543-547. https://doi.org/10.7763/IJSSH.2013.V3.300

Lalaina, Z., Harvey, C. A., Rao, N. S., Dave, R., Chrysostôme, J., Randrianarisoa, J., ... Mackinnon, J. L. (2016). Strategies of smallholder farmers for coping with the impacts of cyclones: A case study from Madagascar. International Journal of Disaster Risk Reduction, 17, 114-122. https://doi.org/10.1016/j.ijdrr.2016.04.013

Lamba, C. T., Herdy, M., \& Kandou, L. F. J. (2017). Gambaran Tingkat Kecemasan pada Warga yang Tinggal di Daerah Rawan Banjir Khususnya Warga di Kelurahan Tikala Ares Kota Manado. Jurnal E-Clinic (ECI), 5(1), 61-65. Retrieved from http://ejournal.unsrat.ac.id

Lee, E., \& Haeyoung Lee. (2019). Disaster awareness and coping: Impact on stress, anxiety , and depression. (December 2018), 311-318. https://doi.org/10.1111/ppc.12351

Mami, M., \& Debarati, G.-S. (2017). Economic Losses, Poverty \& Disasters. Retrieved from https://www.preventionweb.net/files/61119_credeconomiclosses.

Mary, E., \& Emeribe, C. (2014). Flood and Household Preparedness in Benin City , Nigeria. Mediterranean Journal of Social Sciences, 5(1), 547-553. https://doi.org/10.5901/mjss.2014.v5n1p547

Mishra, S., Mazumdar, S., \& Suar, D. (2010). Place attachment and flood preparedness. Journal of Environmental Psychology, 30(2), 187-197. https://doi.org/10.1016/j.jenvp.2009.11.005

Muhammad, P. E., \& Aziz K, A. (2014). Investigating factors for disaster preparedness among residents of Kuala Lumpur. Matural Hazards and Earth System Science, 3683-37809. https://doi.org/10.5194/nhessd-2-3683-2014 


\section{STRADA Jurnal Ilmiah Kesehatan}

DOI: $10.30994 /$ siik.v9i2.489

ISSN: 2252-3847 (print); 2614-350X (online)

Vol.9 No.2 November 2020 Page.1434-1444

Nova, A., Ah, Y., \& Dian, T. R. (2019). Pengalaman Adaptasi Remaja Pasca Bencana Gempa Di Lombok Nusa Tenggara barat. Jurnal Keperawatan Jiwa, 1(2), 36-42. Retrieved from https://e-journal.unair.ac.id/PN

Orpana, H. M., \& Lang, J. (2019). Validation of a brief version of the Social Provisions Scale using Canadian national survey data. Original Quantitative Research, (December). https://doi.org/10.24095/hpcdp.39.12.02

Raikes, J., Timothy, S., Christine, J., \& Claudia, B. (2019). Pre-disaster planning and preparedness for floods and droughts : A systematic review. International Journal of Disaster Risk Reduction, 101207. https://doi.org/10.1016/j.ijdrr.2019.101207

Rodrigues, P. F. S., Pandeirada, J. N. S., \& Bem-haja, P. (2018). The Trait Anxiety Scale for Children: A validation study for European Portuguese children and adolescents. European Journal of Developmental Psychology Developmetrics, (November 2017). https://doi.org/10.1080/17405629.2017.1308249

Sasaki, Y., Aida, J., Tsuji, T., Koyama, S., Tsuboya, T., Saito, T., ... Ichiro, K. (2019). Pre-disaster social support is protective for onset of post-disaster depression: Prospective study from the Great East Japan Earthquake \& Tsunami. Scientific Reports, 1-10. https://doi.org/10.1038/s41598-019-55953-7

Setyo, R. I., Dima, K. N., \& Widya, W. (2019). RELATIONSHIP BETWEEN LEVEL OF DISASTER KNOWLEDGE AND ATTITUDE OF LANDSLIDE DISASTER PREPAREDNESS IN VOLUNTEERS "KELURAHAN TANGGUH" IN MALANG CITY. Journal of Nursing Science, 7(2), 133-144. https://doi.org/Doi10.21776/ub.jik.2019. 007.02.3

Shay, E., Combs, T., Salvesen, D., Detrizio, D., \& Horney, J. A. (2014). Assessing disaster preparedness of officials and residents in Two North Carolina Counties. Geography \& Natural Disasters, 4(October 2015), 1-8. https://doi.org/10.4172/21670587.1000125

Stikova, E. (2016). A Global Public Health Curriculum; 2nd Edition. South Eastern European Journal of Public Health. https://doi.org/doi.org/10.4119/UNIBI/SEEJPH2015-106

Stuart GW. (2013). Principles and Practice of Psychiatric Nursing (10 th). St Louis: Mosby Year Book.

Surbariyanti, Agussabti, \& Imran. (2019). Relationship between the Level of Anxiety with Preparedness of Staff of the Social Service of the Province of Aceh in the Disaster. International Journal of Multicultural and Multireligious Understanding, 6(2), 619626. Retrieved from file:///C:/Users/user name/Downloads/Relationship_between_the_Level_of_Anxiety_with_Pre.pdf

Tuncay, T., Ilgen, M., Engin, G. D., \& Mustafa, K. (2014). The relationship between anxiety, coping strategies and characteristics of patients with diabetes. Health and Quality of Life Outcomes, (December), 1-9. https://doi.org/10.1186/1477-7525-6-79 